\title{
An amphibious mode of life in the intertidal zone: aerial and underwater contribution of Chthamalus montagui to $\mathrm{CO}_{2}$ fluxes
}

\author{
Jacques Clavier ${ }^{1, *}$, Marie-Dorothée Castets ${ }^{1}$, Thomas Bastian $^{1}$, Christian Hily $^{1}$, \\ Guy Boucher ${ }^{2}$, Laurent Chauvaud ${ }^{1}$ \\ ${ }^{1}$ LEMAR, Laboratoire des Sciences de l'Environnement Marin, UMR CNRS 6539, Institut Universitaire Européen de la Mer, \\ Technopôle Brest-Iroise, Place Nicolas Copernic, 29280 Plouzané, France \\ ${ }^{2}$ UMR 5178 (MNHN-CNRS-Paris VI), DMPA, CP 53, 57 rue Cuvier, 75231 Paris cedex 05, France
}

\begin{abstract}
The contribution of the intertidal barnacle Chthamalus montagui to $\mathrm{CO}_{2}$ fluxes via respiration and calcification was measured both in the air and underwater. The mean biomass of the species was $44.92 \mathrm{~g}$ ash-free dry weight (AFDW) $\mathrm{m}^{-2}$ on the coast of Brittany, France. Underwater respiration, determined from changes in dissolved inorganic carbon (DIC), fluctuated from $6.14 \mu \mathrm{mol} \mathrm{g}^{-1}$ $\mathrm{h}^{-1}$ in winter to $13.37 \mu \mathrm{mol} \mathrm{g}^{-1} \mathrm{~h}^{-1}$ in summer. The contribution of $C$. montagui respiration to DIC fluxes for an average daily immersion time of $8 \mathrm{~h}$ was $3.21 \mathrm{mmol} \mathrm{m}^{-2} \mathrm{~d}^{-1}$. Mean aerial $\mathrm{CO}_{2}$ respiration was estimated at $7.60 \mu \mathrm{mol} \mathrm{g}^{-1} \mathrm{~h}^{-1}$ using an infrared gas analyser, corresponding to $5.46 \mathrm{mmol} \mathrm{m}^{-2} \mathrm{~d}^{-1}$ if the mean daily emersion time is $16 \mathrm{~h}$. Net calcification was positive, with a mean value of $1.01 \mu \mathrm{mol}$ $\mathrm{g}^{-1} \mathrm{~h}^{-1}$, corresponding to a $\mathrm{CO}_{2}$ flux of $0.25 \mathrm{mmol} \mathrm{m}^{-2} \mathrm{~d}^{-1}$. The total mean daily emission of $\mathrm{CO}_{2}$ by $C$. montagui populations was $8.92 \mathrm{mmol} \mathrm{m} \mathrm{m}^{-2} \mathrm{~d}^{-1}$. The annual carbon production by the species was $39.07 \mathrm{~g} \mathrm{~m}^{-2} \mathrm{yr}^{-1}$ with relative contributions by aerial respiration, underwater respiration and net calcification of 61,36 and $3 \%$, respectively. The daily ratio of aerial:underwater carbon emission was 1.7, emphasizing the prevalence of aerial respiration and the metabolic adaptation of $C$. montagui to amphibious life.
\end{abstract}

KEY WORDS: $\mathrm{CO}_{2} \cdot$ Barnacle $\cdot$ Respiration $\cdot$ Calcification $\cdot$ Crustacean $\cdot$ Intertidal

Resale or republication not permitted without written consent of the publisher

\section{INTRODUCTION}

Intertidal species are diverse and often proliferate on hard bottoms where they may be subject to prolonged periods of aerial exposure. Those living on hard surfaces are adapted to a changing environment with a regular shift between immersion in water and exposure to air (emersion). Sessile invertebrates living on the upper levels of the shore can thus remain out of water for several hours and desiccation may then become a major impediment to achieving normal biological functions. Low tide is, therefore, often regarded as a time of environmental stress for marine organisms, when feeding is suspended and aerobic respiration may decrease (Sokolova \& Pörtner 2001).

The rocky shore is particularly rich in gastropod and bivalve molluscs and cirripede crustaceans with a large associated mass of calcium carbonate. The density of barnacles often reaches several thousand ind. $\mathrm{m}^{-2}$ (O'Riordan et al. 2004), and they are potentially major $\mathrm{CO}_{2}$ contributors through respiration and calcification (Golléty et al. 2008). Chthamalus montagui Southward, 1976 is a common intertidal barnacle distributed throughout the Mediterranean sea and along the Atlantic shores from Morocco to Scotland (Southward 1976). Densities vary according to wave exposure and types of hard substrata (Herbert \& Hawkins 2006), but maximum abundance is found on the upper shore level (Jenkins 2005), though the species may extend to mid-tide level in the south of its distribution area (Power et al. 2006).

The respiratory behaviour of Chthamalus montagui is described in detail by Davenport \& Irwin (2003). When the barnacles are submerged, water is supplied by the 
movement of cirri, and the prosoma rhythmically extends and withdraws to partially renew water in the mantle cavity. Respiratory exchanges take place on the epithelium of the mantle cavity, the branchiae and the cirri. During the low tide period, chthamalid barnacles are able to hold an air bubble inside the mantle cavity (Grainger \& Newell 1965) and benefit from air that contains 40 times as much $\mathrm{O}_{2}$ as an equivalent volume of air-saturated seawater (Davenport \& Irwin 2003). Gas exchanges with the atmosphere are made possible by opening and closing the respiratory orifice between the mobile upper plates, the pneumostome, for a period depending on desiccation (Grainger \& Newell 1965). C. montagui is therefore highly adapted to prolonged periods in the aerial habitat and is particularly suited to living at high intertidal levels. However, the relative importance of its aerial and underwater respiration is still obscure.

In the context of the increased attention given to $\mathrm{CO}_{2}$ fluxes in marine environments, general information is now available on coastal zone production and respiration (Gazeau et al. 2004, Middelburg et al. 2005). The contribution of intertidal sediments to $\mathrm{CO}_{2}$ fluxes has been studied (Hubas et al. 2006, Spilmont et al. 2007) but the metabolism of intertidal hard substrate communities and populations is comparatively poorly known. Recently, however, Golléty et al. (2008) estimated the production and calcification rates of Chthamalus montagui and the associated $\mathrm{CO}_{2}$ fluxes. Their study first established organic and $\mathrm{CaCO}_{3}$ production based upon the population dynamics of the species. $\mathrm{CO}_{2}$ fluxes were then calculated from the general relationship established by Schwinghamer et al. (1986), to relate production and respiration, and from the molar ratio between the precipitated $\mathrm{CaCO}_{3}$ and the released $\mathrm{CO}_{2}$ (Frankignoulle et al. 1994) for calcification.

Respiration and calcification of intertidal organisms can be affected by tidal influence (immersion-emersion cycle) and season (mainly variation in temperature). The objective of the present study was to test the hypothesis that tidal level and season can affect the contribution of Chthamalus montagui populations to $\mathrm{CO}_{2}$ fluxes, and to improve our understanding of the adaptation of this amphibious species to its environment.

\section{MATERIALS AND METHODS}

Estimation of barnacle densities. Barnacles were sampled in spring and autumn 2005 and 2006 in the context of the REBENT network (www. ifremer.fr/rebent/) (Ehrhold et al. 2006) from 9 sites along the coast of Brittany, France (Fig. 1) to assess the abundance $\left(\mathrm{N}_{i}\right)$ of each species. Live individuals were identified and counted from photographs (surface unit: $25 \mathrm{~cm}^{2}$ ) randomly located in habitat types using the European Nature Information System (EUNIS) classification system (eunis.eea.europa.eu/index.jsp): A1.21, 'Barnacles and fucoids on moderately exposed shores' (100 photographs); A1.211, 'Pelvetia canaliculata and barnacles on moderately exposed littoral fringe rock' (50 photographs); and A1.213, 'Fucus vesiculosus and barnacle mosaics on moderately exposed mid-eulittoral rock' (50 photographs). The mean percentage of Chthamalus montagui dead shells was established in Site MS from 38 randomly distributed photographs.

To estimate the average live individual biomass and mass of calcium carbonate of Chthamalus montagui, we plotted the ash-free dry weight (AFDW) and calcium carbonate weight against abundance (number of individuals) from 21 pairs of biomass-abundance values obtained from natural populations, with a sample size ranging from 8 to 866 individuals. Mean individual biomass $\left(\mathrm{B}_{i}\right)$ and mass of calcium carbonate $\mathrm{C}_{i}$ correspond to the slope of the regression line. For biomass determination, samples were dried at $60^{\circ} \mathrm{C}$ for $48 \mathrm{~h}$ and the AFDW $(\mathrm{g})$ was calculated after combustion $\left(400^{\circ} \mathrm{C}\right.$ for $4 \mathrm{~h})$. The mass of calcium carbonate $\left(\mathrm{CaCO}_{3}, \mathrm{~g}\right)$ corresponds to the difference in ash weight before and after treatment with $0.1 \mathrm{~N} \mathrm{HCl}$. Population biomass $\left(\mathrm{B}_{p_{\text {, }}}\right.$ $\left.\mathrm{g} \mathrm{m}^{-2}\right)$ and mass of $\mathrm{CaCO}_{3}\left(\mathrm{C}_{p}, \mathrm{~g} \mathrm{~m}^{-2}\right)$ were estimated by: $\mathrm{B}_{p}=\mathrm{B}_{i} \times \mathrm{N}_{i}$ and $\mathrm{C}_{p}=\mathrm{C}_{i} \times \mathrm{N}_{i}$ respectively.

Sampling for respiration experiments. Samples of Chthamalus montagui for the underwater respiration assessment were collected seasonally in February (winter), April (spring), August (summer), November

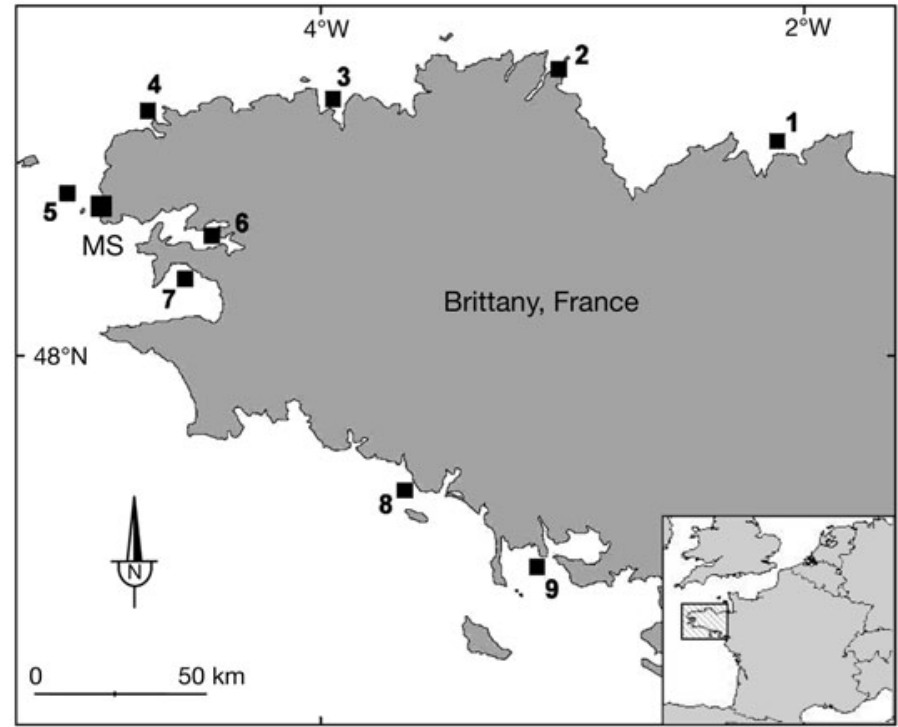

Fig. 1. Sampling sites for barnacle populations (1-9) and metabolic studies (MS) 
(autumn) 2006, and January (winter) 2007. The barnacles were gathered at low tide, near Le Conquet (Site MS, Fig. 1) in a semi-sheltered area with an average density of 56000 ind. $\mathrm{m}^{-2}$, slightly under mean neap tide high-water level. This site is flooded twice daily by the tide and the $C$. montagui populations are thus submerged for an average of $4 \mathrm{~h}$ per tidal cycle. To collect a large number of individuals with minimal disturbance, we collected limpets (Patella vulgata L.) which were, like the surrounding rock surface, naturally covered with $C$. montagui. Following collection, the flesh of the limpets was completely removed. $P$. vulgata shells without barnacles were also taken from the same site to measure any $\mathrm{CO}_{2}$ originating from the biofilm living on the shell alone.

Further samples were collected from the same site in March 2007, when sea surface temperature (12 to $13^{\circ} \mathrm{C}$ ) was close to the annual mean, to evaluate aerial respiration under different experimental conditions. The contribution of limpet shells without barnacles to respiratory fluxes was assessed in August 2006 and January 2007.

Underwater respiration. In the laboratory, samples for underwater incubations were placed on a PVC plate and kept undisturbed in a temperature-controlled room to simulate natural conditions. The barnacles were immersed in flowing seawater pumped from the Bay of Brest (salinity 34.5, ambient temperature) and filtered through a sand filter at the times when natural populations were covered by the rising tide. After $1 \mathrm{~h}$ underwater, the limpet shells, with and without barnacles, respectively were placed into 0.61 ( 0 to 10 shells) and 1.21 (11 to 14 shells) opaque plastic bottles filled with natural filtered seawater. Series of bottles were incubated in the dark for a period of 3 to $4 \mathrm{~h}$ in an $800 \mathrm{l}$ tank filled with flowing seawater pumped from the Bay of Brest (ambient temperature), together with a reference bottle without any shells. This duration corresponded to the period when natural populations were immersed. A hand-driven impeller was mounted in the lid of each bottle and the enclosed water was regularly stirred to ensure thorough mixing.

Total alkalinity (TA) and $\mathrm{pH}$ measurements were made on water samples taken from each bottle at the beginning and end of the incubations. The $\mathrm{pH}$ (total scale) was measured immediately, before alteration by $\mathrm{CO}_{2}$ exchange with the air could occur, using a $\mathrm{pH}$ meter (Radiometer PH240) standardized with Tris-HCl and 2-amminopyridine/ $\mathrm{HCl}$ buffer solutions. TA samples were filtered through $0.7 \mu \mathrm{m}$ Whatman GF/F filters, poisoned with $\mathrm{HgCl}_{2}$ and stored in $250 \mathrm{ml}$ bottles in a cool, dark place. Analyses were carried out within 1 wk. TA (mEq. $\mathrm{l}^{-1}$ ) was determined on $20 \mathrm{ml}$ subsamples by automatic potentiometric titration to the second end point (Radiometer, Titrilab TIM 865) using
$0.01 \mathrm{~mol} \mathrm{l}^{-1} \mathrm{HCl}$. Water temperature was measured at the beginning and end of the incubations. Salinity, phosphate and silicate concentrations were provided by the Marel Iroise Station (IUEM-UBO, Observatoire du Domaine Côtier), located near the pumping station that provided the water for these experiments. The concentration of dissolved inorganic carbon (DIC) was calculated from the $\mathrm{pH}, \mathrm{TA}$, temperature, salinity, phosphate and silicate concentrations (Lewis \& Wallace 1998).

To establish the respiratory quotient $\left(\mathrm{RQ}=\left|\Delta \mathrm{CO}_{2}\right|\right.$ $\left.\Delta \mathrm{O}_{2} \mathrm{l}\right)$ underwater, $\mathrm{O}_{2}$ concentrations $\left(\mu \mathrm{mol} \mathrm{l^{-1 }}\right.$ ) were determined by Winkler titration during a series of incubations in winter and spring. Water samples were transferred into $100 \mathrm{ml}$ glass bottles fitted with ground glass stoppers, and reagents were added immediately. The bottles were shaken and stored immersed in water in the dark until analysis. $\mathrm{O}_{2}$ concentrations were determined by iodometric titration using an automatic titrator (Radiometer, Titrilab TIM 865). RQ corresponds to the slope of the functional regression between $\mathrm{CO}_{2}$ and $\mathrm{O}_{2}$ fluxes ( $\mu \mathrm{mol} \mathrm{l}^{-1} \mathrm{~h}^{-1}$ ).

Aerial respiration. The limpet shells used for air respiration were collected at low tide and placed in a $50 \mathrm{l}$ tank, in the laboratory, where the natural tidal cycle was simulated. During high tide, seawater was continuously transferred from an $800 \mathrm{l}$ reservoir at sea temperature using a timer-controlled pump. The pump was stopped half an hour prior to emersion of natural populations and the tank was emptied by passive drainage. During the following low tide, the samples were placed on a flat acrylic table in a temperaturecontrolled room. They were covered with a 1.9 l opaque chamber with an airtight rubber seal, connected via a closed circuit to an infrared gas analyser (Li-Cor, LI 820). An adjustable pump (Brailsford, TD22N) maintained an air flow of $0.81 \mathrm{~min}^{-1}$ into the circuit. A desiccation column filled with anhydrous calcium sulphate (Drierite) was placed at the gas entry into the analyser to remove humidity from the air. The $\mathrm{CO}_{2}$ partial pressure $\left(\mathrm{pCO}_{2}\right.$; in parts per million, $\mathrm{ppm}=$ $\mu \mathrm{mol} \mathrm{CO}_{2}$ mol air ${ }^{-1}$ ) was displayed on a laptop computer and recorded at $5 \mathrm{~s}$ intervals for about $5 \mathrm{~min}$. Aerial respiration during 'low tide' was measured in this way on 5 sets containing 5, 8, 11, 14 and 17 shells covered with Chthamalus montagui, and a set of control shells without barnacles but with a natural biofilm. $\mathrm{CO}_{2}$ fluxes were measured every hour during emersion time in natural populations. The experiments were repeated in a temperature-controlled room with 6 different levels of air temperature and humidity $\left(4.4^{\circ} \mathrm{C}, 88 \% ; 9.0^{\circ} \mathrm{C}, 64 \% ; 12.4^{\circ} \mathrm{C}, 73 \% ; 15.0^{\circ} \mathrm{C}, 63 \%\right.$; $17.2^{\circ} \mathrm{C}, 58 \%$ and $18.9^{\circ} \mathrm{C}, 43 \%$ ) to mimic usual conditions in the natural environment. The contribution of limpet shells alone to $\mathrm{CO}_{2}$ fluxes was estimated on 15 
samples (from 0 to 14 shells) with and without barnacles.

Calcification. Barnacle shell is mostly produced during immersion periods (Bourget \& Crisp 1975a) as growth requires immediate availability of calcium from seawater (Bourget \& Crisp 1975b). Calcification of Chthamalus montagui was thus estimated during immersion only, using the alkalinity anomaly technique (Smith \& Key 1975) based on the fact that TA decreases by 2 equivalents for each mole of $\mathrm{CaCO}_{3}$ precipitated. This method has proven successful for measuring calcification on isolated organisms (Martin et al. 2006a, Martin et al. 2006b).

The difference between calcification of limpet shells with and without barnacles provides an estimation of Chthamalus montagui calcification. We used natural barnacle populations composed of both living individuals and dead shells. We can therefore estimate net population $\mathrm{CaCO}_{3}$ production corresponding to gross production minus dissolution.

Calcification generates dissolved $\mathrm{CO}_{2}$, causing shifts in the seawater carbonate equilibrium. To calculate the contribution of calcification to $\mathrm{CO}_{2}$ fluxes we estimated $\psi$, the molar ratio of $\mathrm{CO}_{2}$ released by calcification to calcium carbonate precipitated, as a function of the average temperature at each season, according to Frankignoulle et al. (1994).

Data treatment. Underwater respiration in each bottle was calculated by the difference between initial and final concentrations in DIC or $\mathrm{O}_{2}$. The inorganic carbon flux was corrected for calcification influence (Smith \& Key 1975):

$$
\begin{gathered}
R\left(\mathrm{O}_{2}\right)=\frac{\Delta \mathrm{O}_{2} \times v}{\Delta t \times 10^{3}} \\
R(\mathrm{DIC})=\frac{\Delta \mathrm{DIC} \times v}{\Delta t \times 10^{3}}-G \\
G=\frac{\Delta \mathrm{TA} \times v}{2 \times \Delta t}
\end{gathered}
$$

where $R$ is respiration $\left(\mathrm{O}_{2}\right.$ or DIC) in a bottle (mmol $\left.\mathrm{h}^{-1}\right), G$ is net calcification $\left(\mathrm{CaCO}_{3}\right)$ in a bottle $(\mathrm{mmol}$ $\left.\mathrm{h}^{-1}\right), \Delta \mathrm{O}_{2}$ is change in the concentration of dissolved $\mathrm{O}_{2}$ during the incubation $\left(\mathrm{mmol} \mathrm{l}^{-1}\right), v$ is net bottle volume (l); $\Delta t$ is incubation time (h), $\Delta \mathrm{DIC}$ is change in total inorganic carbon $\left(\mathrm{mmol}^{-1}\right)$, and $\Delta \mathrm{TA}$ is change in total alkalinity (mEq. $\mathrm{l}^{-1}$ ).

In the air, the flux of $\mathrm{CO}_{2}\left(\mathrm{mmol} \mathrm{l}^{-1} \mathrm{~h}^{-1}\right)$ corresponds to the linear slope of the change in $\mathrm{CO}_{2}$ partial pressure over time during the incubation period, corrected from the net volume of the enclosure and the incubation time.

Length, width and height of all limpet shells were measured to the nearest $\mathrm{mm}$ and the shell surface $\left(\mathrm{mm}^{2}\right)$ was calculated as a cone. For the limpet shells without barnacles, the slope of the regression between $\mathrm{CO}_{2}$ fluxes and shell surface was calculated. Considering the hypothesis that shell respiration is the same with and without barnacles, fluxes measured for the shells with barnacles were corrected from respiration of shells alone by applying the above relationship to the calculated surface of the shell. The relationship between these corrected fluxes and AFDW biomass of barnacles gives an estimation of fluxes per biomass unit (mmol $\mathrm{l}^{-1} \mathrm{~h}^{-1} \mathrm{~g}^{-1}$ ). As both flux and biomass are affected by natural variability, their relationship was established using a functional regression.

To estimate $\mathrm{CO}_{2}$ and DIC fluxes on an annual scale, we established an Arrhenius plot for air and underwater respiration after logarithmic transformation as a function of $T^{-1}$ as follows:

$$
\ln \text { Flux }=\ln a-\frac{E_{\mathrm{a}}}{\mathrm{k}} \times \frac{1}{T}
$$

where Flux is Chthamalus montagui respiration ( $\triangle \mathrm{DIC}$

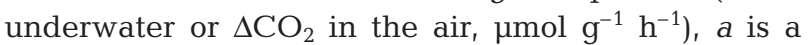
normalization constant, $E_{\mathrm{a}}$ is the activation energy $\left(\mathrm{J}\right.$ mole $\left.{ }^{-1}\right)$, $\mathrm{k}$ is Boltzmann's constant $\left(8.31 \mathrm{~J} \mathrm{~K}^{-1} \mathrm{~mol}^{-1}\right)$, and $T$ is the absolute temperature (K). The relationship was adjusted using a least-squares procedure. Average contributions of $C$. montagui to $\mathrm{CO}_{2}$ fluxes were then calculated both for aerial and underwater mean annual temperatures to test whether temperature could be used to calculate respiration. Atmospheric and sea surface temperatures were measured by the Marel Iroise Station every 20 min over 4 yr (2003 to 2006). Relative humidity percentage was recorded every minute by the Naval Academy at Lanveoc (Bay of Brest). Daily aerial and underwater respiration was calculated for 16 and $8 \mathrm{~h}$, respectively. Calcification was only considered when the barnacles were immersed $\left(8 \mathrm{~h} \mathrm{~d}^{-1}\right)$ and corrected from $\Psi$ to calculate their contribution to $\mathrm{CO}_{2}$ fluxes. Values were extrapolated to $1 \mathrm{~m}^{2}$ using $\mathrm{B}_{p}$.

The slopes of the regression lines of the functional regression between $\mathrm{CO}_{2}$ and $\mathrm{O}_{2}$ fluxes were tested against the null hypothesis of isometry $(b=1)$ using a Z-test (Scherrer 1984). To compare Arrhenius plots for

Table 1. Mean and relative abundance of living barnacles at 9 sites around Brittany ( $\mathrm{n}=3625$ samples). SD given in parentheses

\begin{tabular}{|lcr|}
\hline Taxon & Density (ind. $\left.{ }^{-2}\right)$ & $\%$ \\
\hline Chthamalus montagui & $48463(43550)$ & 72.4 \\
Semibalanus balanoides & $17900(16110)$ & 26.7 \\
Chthamalus stellatus & $501(560)$ & 0.7 \\
Elminius modestus & $71(120)$ & 0.1 \\
\hline
\end{tabular}


underwater and aerial respiration linear regressions, the fitting of the data into the linear regression model was estimated by ANOVA (Sokal \& Rohlf 1981). All average values are reported as mean $\pm \mathrm{SD}$.

\section{RESULTS}

\section{Population characteristics and environmental parameters}

Four barnacle species were present over the 7 sampled sites, and the total abundance of living barnacles was $66935 \pm 56100$ ind. $\mathrm{m}^{-2}$. Semibalanus balanoides (L.) and Chthamalus montagui accounted for over $99 \%$ of this number, with a clear dominance of the latter (Table 1). The mean number of dead C. montagui shells was $4570 \pm 3830 \mathrm{~m}^{-2}$, i.e. $8.6 \%$ of the total shells. Mean individual biomass of C. montagui was $0.93 \pm$ $0.09 \mathrm{mg}$ AFDW ind. ${ }^{-1}\left(\mathrm{R}^{2}=0.83\right)$, and the mass of calcium carbonate was $7.91 \pm 0.74 \mathrm{mg}$ ind. ${ }^{-1}\left(\mathrm{R}^{2}=0.90\right)$. Mean biomass per unit area of $C$. montagui for the 7 sampled sites was then estimated as $44.92 \pm 44.28 \mathrm{~g}$ AFDW $\mathrm{m}^{-2}$, and the mean mass of calcium carbonate as $383.39 \pm 348 \mathrm{~g} \mathrm{CaCO}_{3} \mathrm{~m}^{-2}$.

Temperatures, recorded at the Marel Iroise Station, were slightly lower in the air than at the sea surface (Fig. 2). The average annual temperature was $13.6^{\circ} \mathrm{C}$ underwater and $12.5^{\circ} \mathrm{C}$ in the air. Relative humidity percentages showed high variations at the daily and hourly scale. The average value was $76 \%$ with maximal values in winter (82\%) and minimal in summer (70\%). A weak but statistically significant correlation was observed between average monthly relative humidity and temperature $\left(\mathrm{R}^{2}=0.45, \mathrm{p}=0.04\right)$.

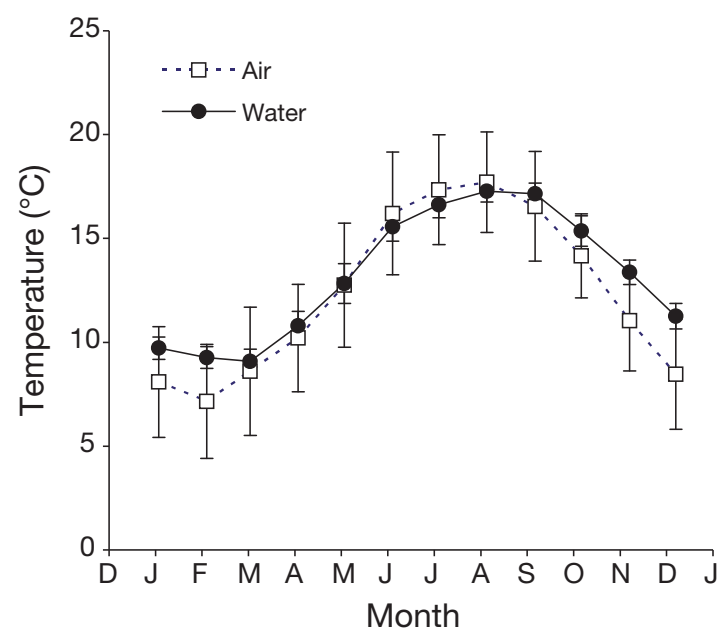

Fig. 2. Monthly variation of mean $( \pm \mathrm{SD})$ sea surface and air temperatures recorded by the Marel Iroise Station near Brest from 2003 to 2006

\section{Underwater respiration}

The mean number of live barnacles per limpet shell was 140. Limpet shells alone represented on average $34 \%$ of underwater $\mathrm{CO}_{2}$ fluxes, with no apparent seasonal pattern. Chthamalus montagui respiration rates, corrected for this contribution, showed a clear seasonal variation, with a 2 -fold difference between maximum fluxes in summer and minimum fluxes in winter (Fig. 3). Respiration rates rose with increasing temperature (Fig. 4) according to the Arrhenius equation, and the high percentage of variance explained (Table 2) indicates that temperature can be used as a proxy for underwater respiration. The respiration rate calculated for the mean annual underwater temperature of $13.3^{\circ} \mathrm{C}$ was $8.94 \mu \mathrm{mol} \mathrm{CO}_{2} \mathrm{~g}^{-1} \mathrm{~h}^{-1}$. Considering an immersion time of $8 \mathrm{~h} \mathrm{~d}^{-1}$, the mean contribution of $C$. montagui respiration to DIC during immersion would be $3.21 \mathrm{mmol} \mathrm{m}^{-2} \mathrm{~d}^{-1}\left(14.06 \mathrm{~g} \mathrm{C} \mathrm{m}^{-2} \mathrm{yr}^{-1}\right)$.

$\mathrm{RQ}$ was $0.99 \pm 0.05$ in winter and $1.00 \pm 0.08$ in spring, and did not differ significantly between these 2 seasons $(Z$-test, $\mathrm{p}>0.05)$. The pooled RQ established from a wide biomass range (0.05 to $1.62 \mathrm{~g}$ AFDW) did not differ significantly from 1 (Z-test, $\mathrm{p}>0.05$ ), indicating a similarity.

\section{Aerial respiration}

The contribution of limpet shells to aerial respiration did not differ significantly between summer and winter (26.2 and $27.5 \%$, respectively, Mann Whitney $U$-test, $p>0.05)$. Thus, we used the average value of $26.9 \%$ to calculate Chthamalus montagui respiration rates during the low tide exposure period. Initial $\mathrm{CO}_{2}$ fluxes, just after emersion, clearly increased with temperature

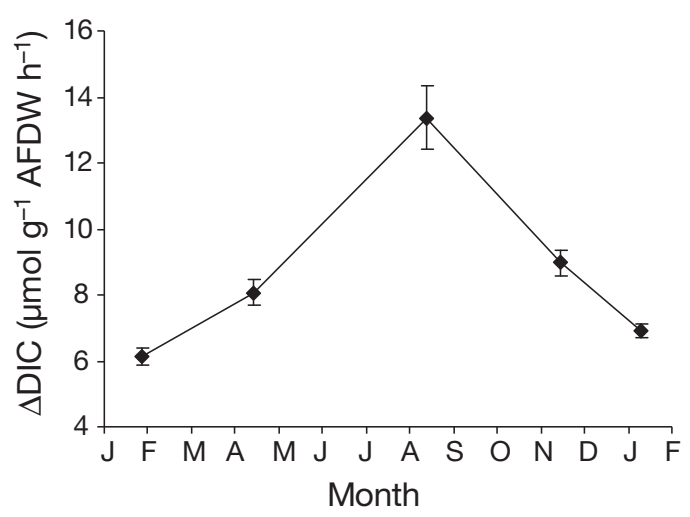

Fig. 3. Chthamalus montagui. Seasonal variation in hourly underwater respiration (dissolved inorganic carbon, DIC) per $g$ ash-free dry weight (AFDW) (mean \pm SD) estimated from incubations in the dark of limpet shells with and without barnacle cover 


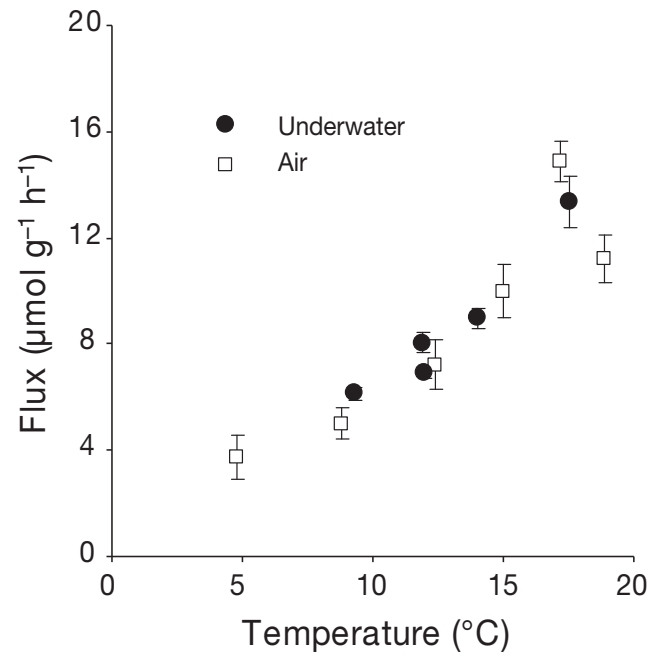

Fig. 4. Chthamalus montagui. Relationship between hourly underwater $(\triangle \mathrm{DIC})$ and aerial $\left(\Delta \mathrm{CO}_{2}\right)$ respiration per $\mathrm{g}$ AFDW and temperature (mean $\pm \mathrm{SD}$ )

Table 2. Parameters of Arrhenius plots (see Eq. 4) relating the logarithm of hourly underwater or aerial respiration per $g$ AFDW to the inverse of absolute temperature. SD given in parentheses

\begin{tabular}{|lccc|}
\hline & Ln $a$ & $E_{\mathrm{a}} / \mathrm{k}$ & $\mathrm{R}^{2}$ \\
\hline Water & $29.60(3.67)$ & $7.86(1.05)$ & 0.95 \\
Air & $28.75(3.85)$ & $7.63(1.10)$ & 0.92 \\
\hline
\end{tabular}

(Fig. 5). For cool, wet conditions, only a slight decrease in population respiration rate could be observed during 7 to $8 \mathrm{~h}$ of air exposure, but a decline in respiration rate with time, perceptible at $63 \%$ humidity, became apparent at $58 \%$ and marked at $43 \%$, where flux values decreased to one third during low tide. Temperature controlled the overall magnitude of respiration, whereas the decrease in $\mathrm{CO}_{2}$ emission during a low tide period varied markedly with atmospheric humidity. Temperature and atmospheric humidity were related in our experiments $\left(\mathrm{R}^{2}=0.79\right)$, as in nature, and our operating procedure did not allow their respective effects to be examined separately. We therefore only established the relationship between mean respiration rate during low tide and temperature values (Fig. 4). The high percentage of variance explained (Table 2) indicates that temperature is also a good proxy for aerial respiration rates. The $\mathrm{CO}_{2}$ respiration rate calculated from the Arrhenius plot was $7.60 \pm 0.83 \mu \mathrm{mol} \mathrm{g}^{-1} \mathrm{~h}^{-1}$ for a mean annual air temperature of $12.5^{\circ} \mathrm{C}$. Considering a daily emersion time of $16 \mathrm{~h}$, the contribution of C. montagui aerial respiration to $\mathrm{CO}_{2}$ production would therefore be $5.46 \mathrm{mmol} \mathrm{m}^{-2} \mathrm{~d}^{-1}\left(23.91 \mathrm{~g} \mathrm{C} \mathrm{m}^{-2} \mathrm{yr}^{-1}\right)$.

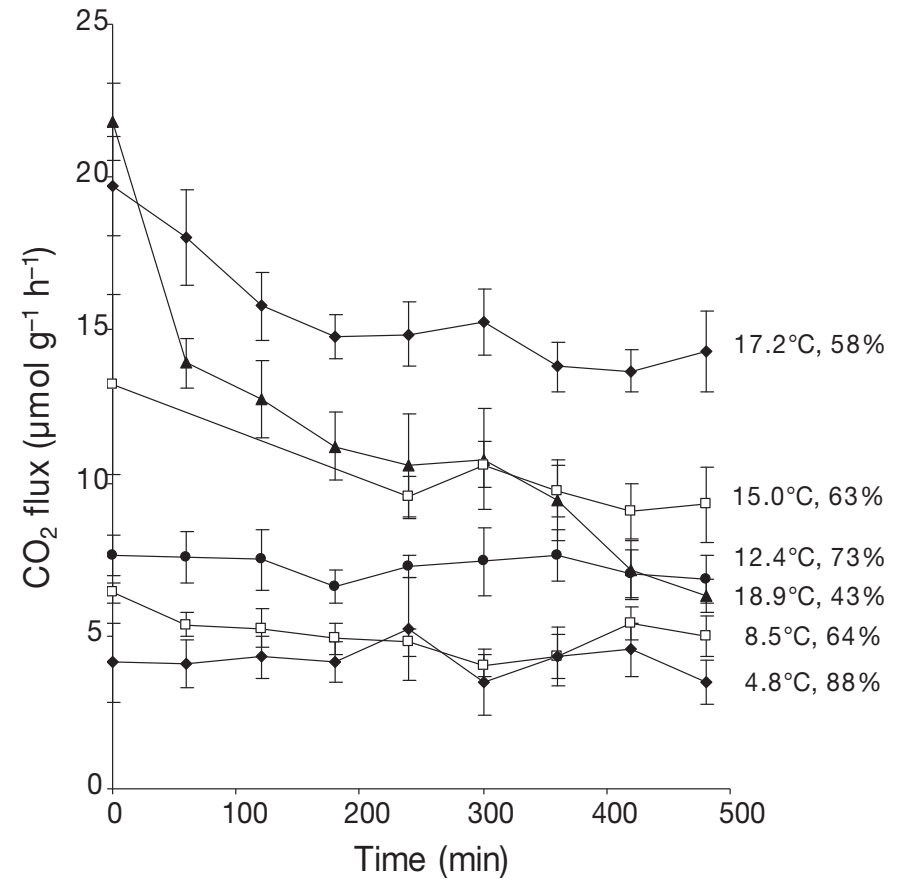

Fig. 5. Chthamalus montagui. Variation in aerial respiration during a low tide period at different temperatures $\left({ }^{\circ} \mathrm{C}\right)$ and humidity levels (\%) estimated from variation in $\mathrm{CO}_{2}$ partial pressure in incubation chambers.

The Arrhenius plots for underwater and aerial respiration (Table 2) did not differ significantly for slopes (ANOVA, $p=0.91$ ) or intercepts (ANOVA, $p=0.49$ ), indicating a similar hourly respiration rate under both conditions.

\section{Calcification}

Net calcification of Chthamalus montagui followed a clear seasonal pattern with negative values in autumn and winter, and positive values in spring and summer (Fig. 6). This was poorly related to temperature $\left(\mathrm{R}^{2}=\right.$ 0.14 for an exponential model), as the minimum values were found in winter and maxima in spring. The net calcification for one year, calculated from the 4 seasons, showed a positive $\mathrm{CaCO}_{3}$ deposition with a mean value of $-1.01 \mathrm{mmol} \mathrm{g}^{-1} \mathrm{~h}^{-1}$ (13.31 $\mathrm{g} \mathrm{CaCO}_{3} \mathrm{~m}^{-2} \mathrm{yr}^{-1}$ ). With a duration of $8 \mathrm{~h}$ immersion per day, the contribution of $C$. montagui net calcification to $\mathrm{CO}_{2}$ fluxes would be $0.25 \mathrm{mmol} \mathrm{m}^{-2} \mathrm{~d}^{-1}\left(1.10 \mathrm{~g} \mathrm{C} \mathrm{m}^{-2} \mathrm{yr}^{-1}\right)$.

\section{Carbon fluxes}

The total daily emission of $\mathrm{CO}_{2}$ by Chthamalus montagui was estimated at $8.92 \mathrm{mmol} \mathrm{m}^{-2} \mathrm{~d}^{-1}$ with contri- 


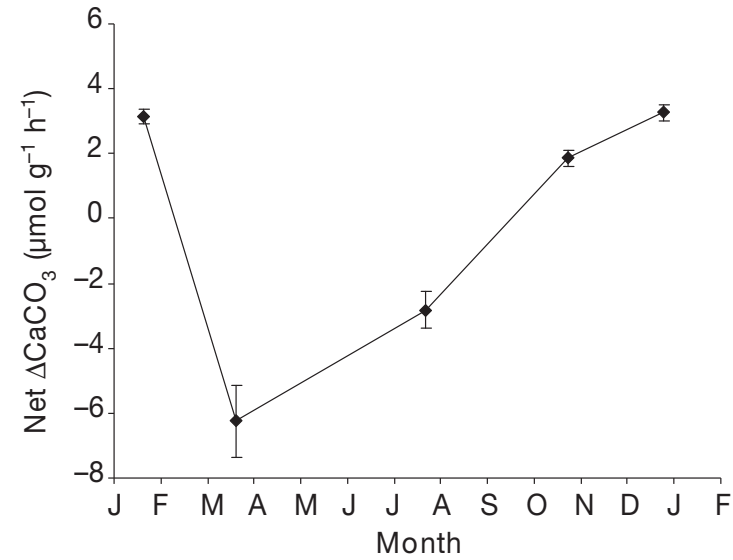

Fig. 6. Chthamalus montagui. Seasonal variation of net calcification rate (mean $\pm \mathrm{SD}$ ) estimated from total alkalinity variation during incubations. Negative values of $\Delta \mathrm{CaCO}_{3}$ correspond to calcification

butions of 61,36 and $3 \%$ for aerial respiration, underwater respiration and net calcification, respectively. Annual carbon production by the species was $39.07 \mathrm{~g}$ $\mathrm{C} \mathrm{m}^{-2} \mathrm{yr}^{-1}$. The ratio of estimated annual hourly respiration by $g$ AFDW in the air and underwater was 0.9 . However, if fluxes are calculated over 1 whole day including $8 \mathrm{~h}$ immersion, the value of this ratio is 1.7 , indicating a prevalence of metabolism during low tide in the contribution to $\mathrm{CO}_{2}$ fluxes.

\section{DISCUSSION}

\section{Biomass estimates}

Chthamalus montagui clearly dominates intertidal hard ground communities of the upper intertidal zone on most European shores (Jenkins 2005), as it does in Brittany. The average density of C. montagui in Brittany is consistent with values found in Ireland, Spain and Italy, which lie between 34000 and 55000 ind. $\mathrm{m}^{-2}$, though a maximum of 320000 ind. $\mathrm{m}^{-2}$ has been found in Portugal (O'Riordan et al. 2004).

\section{Adaptation to intertidal environment}

Temperature and desiccation are the 2 major sources of stress in intertidal environments, although fluctuation in salinity can also induce stress reactions in barnacle populations (Davenport \& Irwin 2003). Due to their mode of life, intertidal barnacles experience rapid and frequent temperature changes. Seasonal variations are predictable, while irregular short-term changes occur during air exposure at low tide (Petersen et al. 1974).
For this reason we assessed aerial, but not underwater, respiration of Chthamalus montagui at different temperatures in spring, as at this time water temperature is close to the annual mean. Had we taken seasonal temperature variation into account, we would have obtained a more precise, but at the same time more variable, relationship between respiration and temperature. We consider that our procedure gives a reasonable estimate of the average annual respiration, even if records from Marel Iroise Station only provide a rough estimate of actual temperature at the regional scale.

The objective of the present study was to obtain a general view of Chthamalus montagui contribution to $\mathrm{CO}_{2}$ fluxes, and the thermal limits used in our experiments resemble normal environmental values recorded in temperate habitats. Extreme values, which are quantitatively negligible over a year, were therefore not considered when establishing the mean annual respiration rates. We found strong relationships between $\mathrm{CO}_{2}$ respiration and temperature, as described by a similar Arrhenius plot, in both underwater and aerial conditions. Even if our results for aerial respiration also depend on desiccation, we can therefore say that, in terms of $\mathrm{CO}_{2}, C$. montagui hourly respiration is similar in the air and underwater at the same temperature, and temperature can therefore be used as a proxy of respiration to estimate annual $\mathrm{CO}_{2}$ fluxes. The difference in daily respiration between the 2 situations is, thus, due to their respective durations. A different response was obtained with the giant barnacle Austromegabalanus psittacus, where the rate of aerial respiration is independent of ambient temperatures between 10 and $20^{\circ} \mathrm{C}$, whereas $\mathrm{O}_{2}$ uptake increases when temperature rises in immersion (López et al. 2003).

Compared with competitors like Chthamalus stellatus, C. montagui is particularly adapted to desiccation (Delany et al. 2003), explaining its distribution at higher tidal levels. The effect of low humidity rates on $\mathrm{CO}_{2}$ fluxes was, however, perceptible below $63 \%$. Percentage air humidity thus controls the short-term metabolic response during a low-tide period, with a notable metabolic decrease at lower humidity levels.

A good survival over $5 \mathrm{~d}$ in dry air (Barnes et al. 1963) indicates the remarkable resistance of chthamalid barnacles to both desiccation and hypoxic conditions. They respond to high desiccation by closing the micropylar aperture (pneumostome) and tight-fitting opercular plates. The percentage of individuals with a closed pneumostome changes with the degree of humidity (Grainger \& Newell 1965), which may account for our observations of respiratory fluxes. In particular, the small number of open pneumostomes at $43 \%$ humidity could explain the discontinuity in apparent temperature dependence of aerial respiration at $18.9^{\circ} \mathrm{C}$ (Fig. 5). 


\section{Underwater and aerial respiration}

Our incubation protocol allowed metabolic variations to be integrated with size over the whole population, taking biological rhythms into consideration. In nature, however, populations are submitted to continuous and often vigorous water movements when submersed, which can improve ventilation in the mantle cavity (Davenport \& Irwin 2003). Natural underwater respiration may therefore be underestimated in our experiments.

We found a similar hourly $\mathrm{CO}_{2}$ emission by Chthamalus montagui in the air and underwater on an hourly basis, but aerial respiration prevails over a tidal cycle, and hence occurs for longer periods of time. The results of previous studies on intertidal cirrepedes are highly variable. In Europe, aquatic $\mathrm{O}_{2}$ uptake by Semibalanus balanoides was 72 to $76 \%$ higher than aerial uptake at the same temperature (Grainger \& Newell 1965), whereas a high capacity for aerial respiration was found for Pollicipes polymerus (Lepadomorpha) with a higher $\mathrm{O}_{2}$ uptake in air-exposed than in submerged animals at each tested temperature (Petersen et al. 1974). No significant reduction in $\mathrm{O}_{2}$ uptake was observed for the Lepadomorpha Calantica spinosa, although gaseous exchange through the peduncle tegument may be involved in the process (Innes 1985). In balanomorph barnacles, aerial respiration capacity of Jehlius cirratus, living in the upper intertidal zone in southern Chile, ranged between 74.5 and $89.5 \%$ of total respiration during submersion (Castro et al. 2001); in the giant barnacle Austromegabalanus psittacus, aerial $\mathrm{O}_{2}$ uptake after $3 \mathrm{~h}$ of air exposure at $10^{\circ} \mathrm{C}$ reached values of over $60 \%$ of $\mathrm{O}_{2}$ uptake during submersion (López et al. 2003).

This adaptation for aerial respiration depends on the position in the intertidal zone, with the capacity to live out of water increasing towards high shore levels (Simpfendörfer et al. 1995, Davenport \& Irwin 2003). In chthamalid barnacles inhabiting the upper part of the intertidal zone, the use of an air bubble with gaseous exchanges via the pneumostome is similar to a rudimentary lung, allowing life in an area where aerial exposure prevails (Simpfendörfer et al. 1995). The effectiveness of this physiological adaptation is limited by desiccation, as the operculum of barnacles is closed tightly when air humidity is low. The variability of this individual behaviour leads to a progressive decrease in respiration at the population level (Grainger \& Newell 1965).

\section{Calcification}

Calcification processes in marine organisms can be assessed in 2 major ways. The calcimass method (car- bonate standing stock) is frequently used (Migné et al. 1998, Chauvaud et al. 2003, Golléty et al. 2008), but the anomaly alkalinity method we used in the present study is considered the most convenient technique for short-term experiments on individual organisms (Gattuso et al. 1999). This second approach also allows both carbonate deposition and dissolution to be evaluated, so as to obtain net calcification.

Our results demonstrate a pronounced seasonal dependence of $\mathrm{CaCO}_{3}$ fluxes, with a predominance of calcification in spring and decalcification in winter, although variation in $\mathrm{pH}$ during the incubations was maximal in spring (0.202), which may lead to underestimation of calcification by promoting dissolution, and minimal in winter (0.072). Maximum calcification in spring and summer is consistent with the general pattern of temperate barnacle growth, which is considerably reduced in winter but high in spring (Crisp \& Bourget 1985, Bourget 1987). Growth in chthamalid barnacle shells is related to deposition of thin calcite layers inside the shell plates, at a rate of about 2 layers $\mathrm{d}^{-1}$ (Bourget \& Crisp 1975a). This pattern indicates a halt in growth during emersion, as immediate availability of calcium from the surrounding water is required for the process (Bourget \& Crisp 1975b).

\section{Carbonate dissolution}

The low value of annual mean net calcification is the result of dynamic processes at the population scale and could be controlled both by internal biological and environmental parameters. The magnitude of carbonate dissolution could be related to a seasonal increase in seawater $\mathrm{pCO}_{2}$ (Borges et al. 2006) with a concomitant decrease in $\mathrm{pH}$. However, the external face of the plates of live barnacles is covered by a membrane (cuticle and epicuticle) (Bourget 1987) that protects their shell walls from dissolution. Moreover, seawater pH was particularly stable during our experiments with a minimum in winter (7.995) and a maximum in spring (8.012), and coupled seasonal variation in carbonate dissolution should therefore be small.

Seawater was supersaturated with respect to calcite with a saturation state $\left(\Omega_{\mathrm{cal}}\right)$ varying from 3.16 in winter to 3.98 in summer, and cannot explain the net dissolution observed in autumn and winter. A decrease of $\mathrm{pH}$ caused by respiration in the experimental enclosures could also promote the dissolution of $\mathrm{CaCO}_{3}$, but seasonal variation in $\mathrm{pH}$ does not match the observed dissolution. On the individual scale, variations in net calcification may be due to carbonate dissolution associated with the physiological acid-base regulation of extra- and intracellular fluids. Buffering of the hemolymph is mainly achieved by an increase in the level of 
bicarbonates, which are formed, in bivalves and other calcified animals, by the dissolution of their $\mathrm{CaCO}_{3}$ exoskeletons (Lindinger et al. 1984).

Metabolic $\mathrm{CO}_{2}$ and products of anaerobic respiration can promote local undersaturation of calcite as observed in bivalves by lowering the $\mathrm{pH}$ of the mantle cavity fluid and blood (Nagarajan et al. 2006). However, chthamalid species are able, because of the air bubble renewed inside the mantle cavity, to maintain oxic condition for several hours (Davenport \& Irwin 2003). Thus, we can hypothesize that the effect of physiological processes on shell dissolution are low at the population level. Dissolution should, therefore, be relatively small in living individuals and negligible on the time scale of our experiments. We can therefore postulate that observed dissolution is mainly due to dead shells among the natural population, whose porous calcite plates are 20 times more soluble than oyster shells (Flessa \& Brown 1983). Dissolution of empty shells may be associated to bioerosion or acidification through local degradation of organic matter by bacterial activity (Smith \& Nelson 2003), leading to a significant decline in the carbonate ion concentration and to a consequent decrease in the saturation state of calcite in seawater.

As the calcification process is very low in winter, net $\mathrm{CaCO}_{3}$ fluxes for this season, which were very similar between our experiments in 2006 and 2007, show mainly dissolution. If we considered dissolution to be constant over the year, a first approximation of the mean associated $\mathrm{CaCO}_{3}$ flux would be $-41.23 \mathrm{~g} \mathrm{CaCO}_{3} \mathrm{~m}^{-2} \mathrm{yr}^{-1}$ for a daily immersion time of $8 \mathrm{~h}$. The mean annual gross $\mathrm{CaCO}_{3}$ deposition can then be calculated as $54.54 \mathrm{~g}$ $\mathrm{CaCO}_{3} \mathrm{~m}^{-2} \mathrm{yr}^{-1}$, which is of the same order of magnitude as the net $\mathrm{CaCO}_{3}$ production estimated by Golléty et al. (2008) (31.5 $\left.\mathrm{g} \mathrm{CaCO}_{3} \mathrm{~m}^{-2} \mathrm{yr}^{-1}\right)$. As densities of living and dead Chthamalus montagui have been estimated at 48463 and 4750 ind. $\mathrm{m}^{-2}$, respectively, an average individual with a mass of $\mathrm{CaCO}_{3}$ of $7.91 \mathrm{mg}$ would be $7.0 \mathrm{yr}$ old, which is consistent with the lifespan of the species, and require about $0.9 \mathrm{yr}$ to dissolve. Dissolution time is, however, underestimated as the mobile plates of the operculum and some plates of the wall, removed by abrasion, were missing from the dead shells, and the high hydrodynamism observed in nature may promote dissolution (Smith \& Nelson 2003). Overall, the dissolution of barnacle shell appears to be a relatively fast process compared with the time required for its formation, which is the main reason for the low contribution of net calcification to $\mathrm{CO}_{2}$ fluxes.

\section{$\mathrm{CO}_{2}$ contribution}

The annual carbon production of Chthamalus montagui (39 $\mathrm{g} \mathrm{C} \mathrm{m}^{-2} \mathrm{yr}^{-1}$ ), mainly due to respiration, is very close to the levels from respiration of the invasive bivalve Potamocorbula amurensis (38 $\mathrm{g} \mathrm{C} \mathrm{m}^{-2} \mathrm{yr}^{-1}$ ) estimated from secondary production (Chauvaud et al. 2003), and the gastropod Crepidula fornicata in the Bay of Brest ( $38 \mathrm{~g} \mathrm{C} \mathrm{m}^{-2} \mathrm{yr}^{-1}$ ) assessed with a method similar to the present study (Martin et al. 2006b). The difference in total carbon production is due to the high rate of $\mathrm{CaCO}_{3}$ dissolution in the barnacle, leading to a low net $\mathrm{CO}_{2}$ production $\left(1 \mathrm{~g} \mathrm{C} \mathrm{m}^{-2} \mathrm{yr}^{-1}\right)$ compared with Potamocorbula amurensis $\left(18 \mathrm{~g} \mathrm{C} \mathrm{m}^{-2} \mathrm{yr}^{-1}\right)$ and Crepidula fornicata $\left(41 \mathrm{~g} \mathrm{C} \mathrm{m}^{-2} \mathrm{yr}^{-1}\right)$, and far from the very high values reported by Golléty et al. (2008) for barnacle populations ( 41 to $152 \mathrm{~g} \mathrm{C} \mathrm{m}^{-2} \mathrm{yr}^{-1}$ ).

Complementary information is still needed on the $\mathrm{CO}_{2}$ taken in by primary producers and released by the metabolism of other organisms to give a complete view of the net production of intertidal hard substrate communities. For example, the contribution from Patella vulgata shells alone was estimated at 27 and $34 \%$ of $\mathrm{CO}_{2}$ emissions into the air and underwater, respectively. This significant $\mathrm{CO}_{2}$ flux may be related to the respiration of shell borers and of a biofilm composed of microfauna and -flora, whose cover changes greatly with substrate complexity (Hutchinson et al. 2006). Our results indicate that Chthamalus montagui is an important contributor to the metabolisms of high intertidal zones, but more information is required at the community level for a comprehensive description of the role of this part of the coastal zone, inhabited by species adapted to an amphibious mode of life.

Acknowledgements. We are grateful to J. Guillou for providing the Marel Iroise data. Special thanks to H. McCombie for her constructive comments to improve the manuscript.

\section{LITERATURE CITED}

Barnes H, Finlayson DM, Piatigorsky J (1963) The effect of desiccation and anaerobic conditions on the behaviour, survival and general metabolism of three common cirripedes. J Anim Ecol 32:233-252

> Borges AV, Schiettecatte LS, Abril G, Delille B, Gazeau F (2006) Carbon dioxide in European coastal waters. Estuar Coast Shelf Sci 70:375-387

Bourget E (1987) Barnacle shells: composition, structure and growth. In: Southward AJ (ed) Barnacle biology. Balkema, Rotterdam, p 267-285

Bourget E, Crisp DJ (1975a) An analysis of the growth bands and ridges of barnacle shell plates. J Mar Biol Assoc UK 55:439-461

Bourget E, Crisp DJ (1975b) Factors affecting deposition of the shell in Balanus balanoides (L.). J Mar Biol Assoc UK 55:231-249

> Castro JM, López DA, Vial MV (2001) Physiological responses to hypoxia and anoxia in Jehlius cirratus (Darwin, 1854) (Cirripedia, Chthamalidae) in the upper intertidal zone. Crustaceana 74:161-170

Chauvaud L, Thompson JK, Cloern JE, Thouzeau G (2003) Clams as $\mathrm{CO}_{2}$ generators: the Potamocorbula amurensis 
example in San Francisco Bay. Limnol Oceanogr 48: 2086-2092

Crisp DJ, Bourget E (1985) Growth in barnacles. Adv Mar Biol 22:199-244

- Davenport J, Irwin S (2003) Hypoxic life of intertidal acorn barnacles. Mar Biol 143:555-563

> Delany J, Myers AA, McGrath D, O'Riordan RM, Power AM (2003) Role of post-settlement mortality and 'supply-side' ecology in setting patterns of intertidal distribution in the chthamalid barnacles Chthamalus montagui and C. stellatus. Mar Ecol Prog Ser 249:207-214

Ehrhold A, Harnon D, Guillaumont B (2006) The REBENT monitoring network, a spatially integrated, acoustic approach to surveying nearshore macrobenthic habitats: application to the Bay of Concarneau (South Brittany, France). ICES J Mar Sci 63:1604-1615

Flessa KW, Brown TJ (1983) Selective solution of macroinvertebrate calcareous hard parts: a laboratory study. Lethaia 16:193-205

Frankignoulle M, Canon C, Gattuso JP (1994) Marine calcification as a source of carbon dioxide: positive feedback of increasing atmospheric $\mathrm{CO}_{2}$. Limnol Oceanogr 39:458-462

Gattuso JP, Allemand D, Frankignoulle M (1999) Photosynthesis and calcification at cellular, organismal, and community levels in coral reefs: a review on interactions and control by carbonate chemistry. Am Zool 39:160-183

Gazeau F, Smith SV, Gentili B, Frankignoulle M, Gattuso JP (2004) The European coastal zone: characterization and first assessment of ecosystem metabolism. Estuar Coast Shelf Sci 60:673-694

Golléty C, Gentil F, Davoult D (2008) Secondary production, calcification and $\mathrm{CO}_{2}$ fluxes in the cirripedes Chthamalus montagui and Elminius modestus. Oecologia 155:133-142

Grainger F, Newell GE (1965) Aerial respiration in Balanus balanoides. J Mar Biol Assoc UK 45:469-479

> Herbert RJH, Hawkins SJ (2006) Effect of rock type on the recruitment and early mortality of the barnacle Chthamalus montagui. J Exp Mar Biol Ecol 334:96-108

> Hubas C, Davoult D, Cariou T, Artigas LF (2006) Factors controlling benthic metabolism during low tide along a granulometric gradient in an intertidal bay (Roscoff Aber Bay, France). Mar Ecol Prog Ser 316:53-68

Hutchinson N, Nagarkar S, Aitchison JC, Williams GA (2006) Microspatial variation in marine biofilm abundance on intertidal rock surfaces. Aquat Microb Ecol 42:187-197

Innes AJ (1985) Oxygen uptake and haemolymph oxygen tension in the stalked barnacle Calantica spinosa. NZ J Zool 12:111-117

Jenkins SR (2005) Larval habitat selection, not larval supply, determines settlement patterns and adult distribution in two chthamalid barnacles. J Anim Ecol 74:893-904

Lewis E, Wallace DWR (1998) Program developed for $\mathrm{CO}_{2}$ system calculations. ORNL/CDIAC-105. Carbon Dioxide Information Analysis Center, Oak Ridge National Laboratory, US Department of Energy, Oak Ridge, TN

Lindinger MI, Lauren DJ, McDonald DG (1984) Acid-base balance in the sea mussel, Mytilus edulis. III. Effects of environmental hypercapnia on intra- and extracellular acid-base balance. Mar Biol Lett 5:371-381

López DA, Castro JM, González ML, Simpfendörfer RW (2003) Physiological responses to hypoxia and anoxia in the giant barnacle, Austromegabalanus psittacus (Molina, 1782). Crustaceana 76:533-545

Martin S, Castets MD, Clavier J (2006a) Primary production, respiration and calcification of the temperate free-living

Editorial responsibility: Pei-Yuan Qian,

Kowloon, Hong Kong, China coralline alga Lithothamnion corallioides. Aquat Bot 85: $121-128$

Martin S, Thouzeau G, Chauvaud L, Jean F, Guérin L, Clavier J (2006b) Respiration, calcification, and excretion of the invasive slipper limpet, Crepidula fornicata L.: implications for carbon, carbonate, and nitrogen fluxes in affected areas. Limnol Oceanogr 51:1996-2007

Middelburg JJ, Duarte CM, Gattuso JP (2005) Respiration in coastal benthic communities. In: del Giorgio PA, Williams LPJ (eds) Respiration in aquatic ecosystems. Oxford University Press, Oxford, p 206-224

Migné A, Davoult D, Gattuso JP (1998) Calcium carbonate production of a dense population of the brittle star Ophiothrix fragilis (Echinodermata: Ophiuroidea): role in the carbon cycle of a temperate coastal ecosystem. Mar Ecol Prog Ser 173:305-308

Nagarajan R, Lea SEG, Goss-Custard JD (2006) Seasonal variations in mussel, Mytilus edulis L. shell thickness and strength and their ecological implications. J Exp Mar Biol Ecol 339:241-250

O'Riordan RM, Arenas F, Arrontes J, Castro JJ and others (2004) Spatial variation in the recruitment of the intertidal barnacles Chthamalus montagui Southward and Chthamalus stellatus (Poli) (Crustacea: Cirripedia) over an European scale. J Exp Mar Biol Ecol 304:243-264

Petersen JA, Fynn HJ, Johansen K (1974) Eco-physiological studies of an intertidal crustacean, Pollicipes polymerus (Cirripedia, Lepadomorpha): aquatic and aerial respiration. J Exp Biol 61:309-320

> Power AM, Delany J, McGrath D, Myers AA, O'Riordan RM (2006) Patterns of adult abundance in Chthamalus stellatus (Poli) and C. montagui Southward (Crustacea: Cirripedia) emerge during late recruitment. J Exp Mar Biol Ecol 332:151-165

Scherrer B (1984) Biostatistique. Gaetan Morin, Montreal, Paris

> Schwinghamer P, Hargrave B, Peer D, Hawkins CM (1986) Partitioning of production and respiration among size groups of organisms in an intertidal benthic community. Mar Ecol Prog Ser 31:131-142

Simpfendörfer RW, Vial MV, López DA, Verdala M, González ML (1995) Relationship between the aerobic and anaerobic metabolic capacities and the vertical distribution of three intertidal sessile invertebrates: Jehlius cirratus (Darwin) (Cirripedia), Perumytilus purpuratus (Lamarck) (Bivalvia) and Mytilus chilensis (Hupé) (Bivalvia). Comp Biochem Physiol B 111:615-623

Smith SV, Key GS (1975) Carbon dioxide and metabolism in marine environments. Limnol Oceanogr 20:493-495

Smith AM, Nelson CS (2003) Effects of early sea-floor processes on the taphonomy of temperate shelf skeletal carbonate deposits. Earth Sci Rev 63:1-31

Sokal RR, Rohlf FJ (1981) Biometry. Freeman and Company, New York

Sokolova IM, Pörtner HO (2001) Physiological adaptations to high intertidal life involve improved water conservation abilities and metabolic rate depression in Littorina saxatilis. Mar Ecol Prog Ser 224:171-186

Southward AJ (1976) On the taxonomic status and distribution of Chthamalus stellatus (Cirripedia) in the north-east Atlantic region: with a key to the common intertidal barnacle in Britain. J Mar Biol Assoc UK 56:1007-1028

Spilmont N, Migné A, Seuront L, Davoult D (2007) Short-term variability of intertidal benthic community production during emersion and the implication in annual budget calculation. Mar Ecol Prog Ser 333:95-101

Submitted: October 1, 2007; Accepted: September 4, 2008 Proofs received from author(s): January 14, 2009 